\title{
COVID-19 Tedavisinde Favipiravir Kullanımı
}

\section{Favipiravir Use in COVID-19 Treatment}

\author{
Emre KARA'(IID), Ahmet Çag̃kan INKAYA²(IID), Kutay DEMiRKAN'(I̊D), Serhat ÜNAL 2(IiD) \\ ${ }^{1}$ Hacettepe Üniversitesi Eczacılık Fakültesi, Klinik Eczacılık Anabilim Dalı, Ankara, Türkiye \\ 2 Hacettepe Üniversitesi Tıp Fakültesi, İnfeksiyon Hastalıkları ve Klinik Mikrobiyoloji Anabilim Dalı, Ankara, Türkiye
}

Makale atıfı: Kara E, Inkaya AÇ, Demirkan K, Ünal S. COVID-19 tedavisinde favipiravir kullanımı. FLORA 2021;26(1):1-11.

\section{ÖZ}

Aralık 2019 tarihinde tanımlanan yeni koronavirüs hastalığı (COVID-19) için etken olan SARS-CoV-2'ye karşı etkinliği kısmen gösterilmiş tedavi seçenekleri olmakla birlikte sağ kalım üzerine etkisi kanıtlanmış bir ilaç henüz geliştirilememiştir. Farklı endikasyonlar için kullanılmakta veya geliştirilmekte olan birçok kimyasal, in vitro çalışmalarda gözlenen etkilerine dayanılarak, tedavi amaçlı kullanıma alınmıştır. Bu ilaçlardan biri olan favipiravir ilk olarak pandeminin başlangıç merkezi olan Wuhan'da kullanılmıştır. Infeksiyonun dünyaya yayılmaya başlamasından itibaren Italya, Japonya, Rusya, Ukrayna, Özbekistan, Moldova ve Kazakistan, Bangladeş, Mısır, Hindistan gibi ülkelerin yanı sıra ülkemizde de kullanılmaktadır. Favipiravirin etkinliğini değerlendirmek için yapılmış ve yayımlanmış az sayıda çalışma vardır ancak çok sayıda çalışma devam etmektedir. Bu derlemede literatürde favipiravirin COVID-19 tedavisinde etkinliğini bildiren çalışma ve vaka raporlarının gözden geçirilmesi ve değerlendirilmesi amaçlanmıştır. Kaynak taramasıyla 223 sonuca ulaşılmıştır, bu sonuçlardan 210 yazıya tam erişim sağlanabilmiştir ve toplam 34 yazı analize dahil edilmiştir. Derleme kapsamında favipiravirin farmakolojisi başlığı altında farmakokinetik, farmakodinamik özelliklere ek olarak istenmeyen etkiler ve ilaç etkileşimlerinden bahsedilmiştir. Favipiravir, COVID-19 hastalarının tedavisi için seçeneklerden biridir ancak çok daha fazla hastanın dahil edildiği ve daha uzun takip sürelerini içeren randomize, kontrollü çalısmaların planlanması ve devam eden çalışmaların sonuçlarının değerlendirmesi gerekmektedir.

Anahtar Kelimeler: COVID-19; SARS-COV-2; Favipiravir

\section{ABSTRACT \\ Favipiravir Use in COVID-19 Treatment}

\section{Emre KARA', Ahmet Çag̃kan inKAYA ${ }^{2}$, Kutay DEMIRKAN', Serhat ÜNAL ${ }^{2}$}

\footnotetext{
${ }^{1}$ Department of Clinical Pharmacy, Hacettepe University Faculty of Pharmacy, Ankara, Turkey

${ }^{2}$ Department of Infectious Diseases and Clinical Microbiology, Hacettepe University Faculty of Medicine, Ankara, Turkey
}

There are treatment options with partially shown efficacy against SARS-CoV-2. A drug with proven effect on survival has not yet been developed for the new coronavirus disease (COVID-19) defined in December 2019. Many chemicals that are being used or developed for different indications have been used for COVID-19 treatment, based on their effects observed in in vitro studies. Favipiravir, one of these drugs, was first used in Wuhan, the starting center of the pandemic. Since the spread of the infection to the world, it has been used in our country as well as countries such as Italy, Japan, Russia, Ukraine, Uzbekistan, Moldova and Kazakhstan, Bangladesh, Egypt, India. There are few studies conducted and published to evaluate the effectiveness of favipiravir, but many studies are ongoing. In this review,

Geliș Tarihi/Received: 18/12/2020 - Kabul Ediliș Tarihi/Accepted: 07/01/2021

${ }^{\bullet}$ Telif Hakkı 2021 Flora. Makale metnine www.floradergisi.org web adresinden ulașılabilir 
it was aimed to review and evaluate the studies and case reports reporting the efficacy of favipiravir in the treatment of COVID-19. With the literature search, 223 results were reached, 210 articles were fully accessed, and a total of 34 articles were included in the analysis. In the scope of the review, under the title of pharmacology of favipiravir, adverse effects and drug interactions in addition to pharmacokinetic and pharmacodynamic properties are mentioned. Favipiravir is one of the options for the treatment of COVID-19 patients, but randomized, controlled trials involving much more patients and longer follow-up periods need to be planned and the results of ongoing trials evaluated.

Key Words: COVID-19; SARS-CoV-2; Favipiravir

\section{GiRiș}

Aralık 2019 tarihinde bașlamıs olan yeni koronavirüs hastalığ1 (COVID-19) ülkemizde de Mart 2020'den beri etkisini sürdürmektedir. Hastalığın etkeni olan SARS-CoV-2'ye karșı etkinliği kısmen gösterilmis tedavi seçenekleri olmakla birlikte randomize, kontrollü, güçlü çalıșmalarla sağ kalım üzerine etkisi kanıtlanmıs bir ilaç henüz geliștirilememistir.

Bașka endikasyonlar için kullanılmakta veya gelistirilmekte olan birçok kimyasal, in vitro calıșmalarda gözlenen etkilerine dayanılarak, klinikte tedavi amaçlı kullanıma alınmıstır. Bu ilaçlardan biri, Japonya'da influenza A için 2014 yllından beri kullanılmakta olan favipiravirdir(1). Favipiravir ilk olarak pandeminin bașlangıc merkezi olan Wuhan'da kullanılmıștır. Hastalığın dünyaya yayılmaya bașlamasıly birlikte İtalya, Japonya, Rusya, Ukrayna, Özbekistan, Moldova ve Kazakistan, Banglades, Misır, Hindistan gibi ülkelerin yanı sıra ülkemizde de kullanılmıstır ve halen bu ülkelerin bazılarında kullanılmaya devam edilmektedir.

Favipiravirin etkinliğini değerlendiren yayınlanmıs az sayıda calıșma olsa da, "clinicaltrials.gov" web sitesine kayıt edilmis cok sayıda çalıșma devam etmekte ve önümüzdeki dönemde tamamlanmaları ve yayınlanmaları beklenmektedir. $\mathrm{Bu}$ derleme ile literatürde favipiravir kullanımını ve COVID-19 tedavisinde etkinliğini bildiren calıșma ve vaka raporlarının gözden geçirilmesi ve değerlendirilmesi amaçlanmıștır.

\section{Literatuir Taraması}

Literatür taraması 13 Kasım 2020 tarihinde "Medline Pubmed" veritabanı kullanılarak yapilmıștır. Tarama için 'favipiravir' ve 'COVID-19' anahtar kelimeleri kullanılmıstır ("favipiravir"[Supplementary Concept] OR "favipiravir"[All Fields]) AND ("severe acute respiratory syndrome coro- navirus 2"[Supplementary Concept] OR "severe acute respiratory syndrome coronavirus 2"[All Fields] OR "ncov"[All Fields] OR "2019 ncov"[All Fields] OR "covid 19"[All Fields] OR "sars cov 2"[All Fields] OR "coronavirus"[All Fields] OR "cov"[All Fields]). Kaynak taramasiyla 223 sonuca ulașılmıștır, bu sonuçlardan 210 yazıya tam erișim sağlanabilmiștir ve toplam 34 yazı analize dahil edilmiștir (Șekil 1).

\section{Favipiravirin Farmakolojisi}

Favipiravir, bir ön ilaçtır ve ribonükleik asit (RNA) bağımlı RNA polimeraz inhibitörü olarak etki gösteren; influenza A ve Ebola bașta olmak üzere, Batı Nil virüsü, Sarhhumma virüsü, Lassa virüs gibi infeksiyon etkenlerine karșı etkinliği gösterilmis bir antiviral ajandır ${ }^{[1-4]}$. Vero E6 hücrelerinde SARS-CoV-2 infeksiyonunu inhibe ettiği gösterilmiștir (EC50 değeri $61.88 \mu \mathrm{M})^{[5]}$. Bir ön ilac olarak öncelikle ribozile ve fosforile edilerek hücre içinde aktif metaboliti olan T-705RTP'ye dönüserek etki göstermektedir ${ }^{[1,6]}$.

\section{Farmakokinetik ve Farmakodinamik Özellikleri}

Oral alım sonrası yaklassı \%95 gibi yüksek bir biyoyararlanım düzeyi ile kan dolașımına ulașmaktadır. Tek doz uygulama sonrası 2 saat içerisinde maksimum kan konsantrasyonuna (Cmaks) ulasmaktadır. Proteine bağlanma oranı \%54, dağılım hacmi 10-20 litre ve plazma yarı ömrü yaklașı olarak 2-5.5 saattir. İnaktif metabolitlerinden biri olan hidroksile formu hızlı bir sekilde böbrek yoluyla atılmaktadır. Eliminasyon sürecinde temelde aldehit oksidaz olmak üzere, ksantin oksidaz enzimi de rol oynamaktadir. Favipiravir sitokrom P450 (CYP) enzim sistemi için bir substrat olmadığı için, bu enzimler favipiravir metabolizasyonda rol oynamamaktadır. Ancak favipiravir CYP2C8 izoenzimini inhibe ettiği için, bu enzimle metabo- 


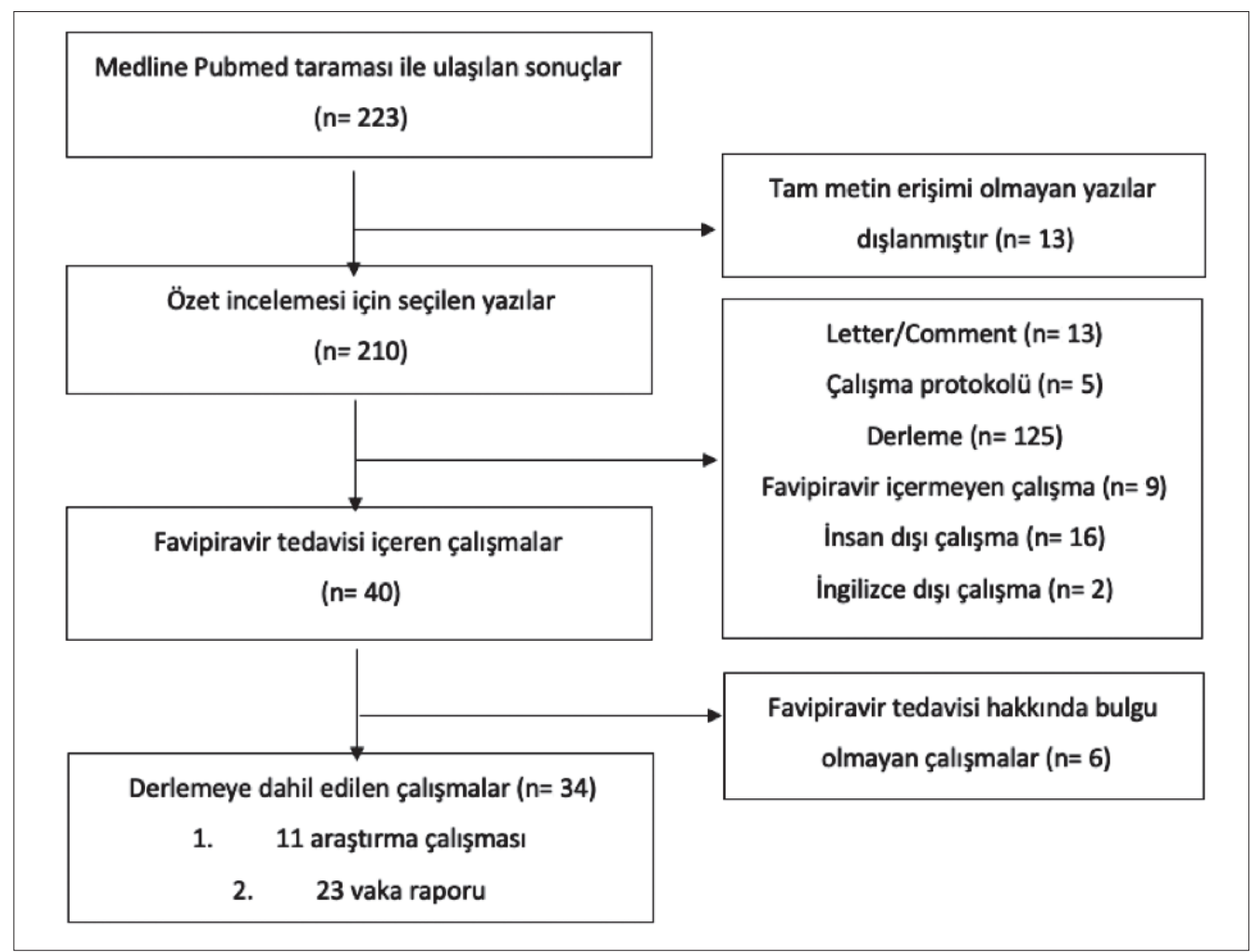

Şekil 1. Literatür taraması sonucu analize dahil edilen ve dışlanan çalışmalar.

lize olan ilaçlarla birlikte kullanımda, diğer ilacın kan düzeyinde ve etkinliğinde artıs gözlenebilmektedir. Böbrek ve karaciğer fonksiyonlarının favipiravir konsantrasyonu üzerinde etkili olduğuna dair bazı veriler olsa da doz ayarlama gerekliliği konusunda herhangi bir öneri bulunmamaktadır ${ }^{[7,8]}$.

Favipiravir etkinliği değerlendirildiğinde, Ebola virüs için saptanan EC50 değerinin $(67 \mu \mathrm{mol} / \mathrm{L})$ influenzaya yönelik belirlenmis olan değerden $(0.48$ $\mu \mathrm{mol} / \mathrm{L}$ ) cok daha yüksek olduğu saptanmıștır. "Ebola tedavisi için favipiravir (JIKI)" (JIKI kelimesi, calıșmanın yapıldığı bölgede konusulan Kissi dilinde umut anlamina gelmektedir.) calısmasında oldukça yüksek bir dozda (ilk gün $6000 \mathrm{mg}$ yükleme, daha sonra ise 9 gün boyunca $2400 \mathrm{mg} /$ gün idame) kullanılmıștır, ancak bu dozla bile hedef konsantrasyona ulașlamadığı anlașılmıștır. SARS-CoV-2 için ise $61.88 \mu \mathrm{mol} / \mathrm{L}$ 'lik EC50 değeri gereksinimi olduğu gösterilmiștir ${ }^{[5]}$. İnfluenza tedavisinde favipiravir için Japonya'da doz ilk gün 1600 mg yükleme, daha sonra ise 2-5 gün boyunca $1200 \mathrm{mg} /$ gün idame olarak onaylanmıștır ${ }^{[9]}$. Az sayıda preklinik ve in vitro veri olması nedeniyle ve in vitro/in vivo çalıșmalarda dozun belirlenmesi esas amaçlar arasında yer almadığı için, optimal dozun tahmin edilmesi ve belirlenmesi güctür. Doi ve arkadașları tarafından yapılan çalıșmanın yöntem bölümünde ilk gün $3600 \mathrm{mg}$, sonraki günler ise $1600 \mathrm{mg} /$ gün dozun sağlıklı gönüllluilerde, $60 \mu \mathrm{g} / \mathrm{mL}$ plazma konsantrasyonu olușturan doz olarak belirlendiği bildirilmiștir $^{[10]}$. Farmakokinetik simülasyon yüksek doz favipiravir (ilk gün $4800 \mathrm{mg}$ yükleme, daha sonra ise 9 gün boyunca $3200 \mathrm{mg} /$ gün idame) uygulanmasını takiben $70 \mu \mathrm{g} / \mathrm{mL}$ 'lik vadi konsantrasyonuna ulașılabileceğini ön görmektedir ${ }^{[11]}$. Kritik hastalarda ( $\mathrm{n}=5$ ) nazogastrik yolla $1600 \mathrm{mg}$ yükleme, daha sonra 2-5 gün boyunca 1200 $\mathrm{mg} /$ gün uygulanmasıyla, sağlıklı gönüllü̈lere kıyasla düșük kan düzeyi oluștuğu anlașılmıștır ${ }^{[12]}$. Bir hemodiyaliz hastasında favipiravir konsantrasyonunun değerlendirildiği bir vaka raporunda favipiravir kan konsantrasyonunun daha önce hemodiyalize girmeyen hastalarda yapilan calısmalarla benzer bir seyir gösterdiği saptanmıștır ${ }^{[13]}$.

$\mathrm{Bu}$ belirsizliklere rağmen sonlanmıs ve devam etmekte olan birçok calıșmada favipiravir dozu ilk 
gün 12 saatte bir 1600 mg yüklemenin ardından, 12 saatte bir 600 mg idame veya ilk gün 12 saatte bir $1800 \mathrm{mg}$ yüklemenin ardından, 12 saatte bir 800 mg idame olarak uygulanmaktadır.

\section{İstenmeyen Etkiler}

Favipiravir az sayıda, hafif düzeyde istenmeyen etkileriyle iyi bir güvenilirlik profiline sahiptir. Hiperürisemi en sık gözlenen istenmeyen etkidir, sıklığı doza bağımlı olarak artmaktadır. Hiperürisemi için öne sürülen mekanizma ürik asit üretiminde artış ve ürik asit atılımında azalmadır. Favipiravir ve metaboliti favipiravir hidroksit organik anyon transporter (OAT) 1 ve 3'ü inhibe ederek tübüler ürik asit sekresyonunu azaltmaktadır; ayr1ca favipiravir hidroksit, ürat transporter üzerinden ürik asit geri emilimini artırabilir ${ }^{[14]}$. Favipiravir tedavisiyle ürik asit düzeyindeki değișimler, tedavi süresinin kısa olmasından dolayı klinik semptomlara yol açmamaktadır.

Favipiravir tedavisi altında, protrombin zamanında artıs, eritrosit serisinde (eritrosit, hemoglobin, hematokrit) azalma ve lenfopeni gözlenebilmektedir. Ayrica, alanin aminotransferaz (ALT), aspartat aminotransferaz (AST) ve trigliserit duizeylerinde artıs, diyare, nötropeni, lökopeni diğer sık gözlenen istenmeyen etkiler arasinda belirtilmektedir ${ }^{[15]}$. Favipiravirin QT'yi uzatmadığı görülmüștür ${ }^{[16]}$.

Favipiravirin teratojenik ve embriyotoksik potansiyeli olduğu düșünülmektedir. Japonya ilaç onay raporunda bu konuda önemli uyarılarda bulunulmuștur. Bu raporda gebelik veya gebelik riski durumlarında favipiravir yerine alternatif tedavilerin kullanılması, tedavi süresince ve tedavi sonrasında yedi gün boyunca her iki cinsiyet için de kontrasepsiyon yöntemlerinin uygulanması önerilmektedir ${ }^{[14]}$.

\section{İlaç Etkileșimleri}

Pirazinamid ve diğer ürik asit düzeyini arttıran ilaçlarla ile birlikte kullanımda hiperürisemi riski artmaktadir. Asiklovir, favipiravirin aktif formuna geçișini ve dolayısıyla antiviral etkinliğini geciktirebilmekte ve azaltabilmektedir. Repaglinid CYP2C8 enzimi ile metabolize olduğu için favipiravir ile birlikte kullanımda repaglinid düzeyinde ve etkilerinde artıs beklenmektedir. Teofilin favipiravirin kan düzeyini ve etkilerini arttırabilir. Parasetamol ile birlikte kullanımda parasetamol etkisi artabilir ${ }^{[6]}$.

\section{Klinik Çalıșmalar}

\section{Etkinlik}

Favipiravirin COVID-19 hastalarında etkinliğini değerlendiren ilk çalıșmalardan biri Cai ve arkadașları tarafından Cin'de yapılan, açık etiketli, randomize olmayan, öncesi-sonrası metodolojisi kullan1lan, kontrolliu calıșmadır. Bu çalıșma 30 Ocak ve 14 Subat 2020 tarihleri arasında yürütülmüstür ve calıșmaya polimeraz zincir reaksiyonu (PCR) pozitif hastalar dahil edilmiștir. Uygun hastalar favipiravir grubuna, 24-30 Ocak 2020 tarihleri arasında lopinavir/ritonavir tedavisi uygulanmıs hastalar ise kontrol grubuna dahil edilmiștir. Çalıșmaya hastalığın bașlangıcından itibaren yedi günden daha az süre içinde tedavi verilen hastalar dahil edilmiștir. Ciddi klinik durumu olan (șu sekilde faktörlerden biri olan: dinlenme halinde > 30/dakika solunum sayıs1, oksijen saturasyonunun \%93'ün altında olması, oksijenasyon indeksinin $300 \mathrm{mmHg}$ 'nın altında olması, solunum yetmezliği, sok ve/veya yoğun bakım izlemi ve tedavisi gerektiren diğer yetmezlikler) hastalar calıșma dıșında bırakılmıștır. Ayrıca kronik karaciğer ve böbrek hastalığı olan hastalar, gebe ve emziren kadınlar calıșmadan dı̣̦lanmıștır. Favipiravir ilk gün 12 saatte bir 1600 $\mathrm{mg}$ yükleme, daha sonra ise 14 . güne kadar 12 saatte bir $600 \mathrm{mg}$ idame dozda uygulanmıstır. Tedavi süresi viral klirense ulașma zamanı veya 14 gün olarak belirlenmiștir. Bütün hastalara ek olarak inhalasyon yoluyla $60 \mu \mathrm{g}$ interferon-a1b verilmistir. Tedavi etkinliği için viral klirense ulașma süresi ve toraks bilgisayarlı tomografi (BT)'deki düzelme oranı değerlendirilmiștir. Çalıșma kapsamında temel özellikleri benzerlik gösteren 35 hasta favipiravir grubuna, 45 hasta ise lopinavir/ritonavir grubuna dahil edilmiștir. Sonuc olarak favipiravir grubunda ortanca dört günde, kontrol grubunda ise ortanca 11 günde viral klirense ulașılmıștır $(p<0.001)$. Tedavinin 4. ve 9. gününde toraks BT bulgularında iki grup arasında anlamlı bir farklllık gözlenmemiștir, ancak 14. günde favipiravir grubunda daha fazla düzelme olduğu görülmüstür (\%91.4 ve $\% 6.2, p=0.004)$. Ayrıca tedavinin ilk yedi günü içinde viral klirense ulașlan hastalarda toraks BT'de düzelmenin daha fazla olduğu saptanmıștır. Cok değișkenli analizlerde toraks BT'de ve viral klirenste düzelmenin favipiravir grubunda anlamlı olarak daha fazla olduğu saptanmıstır ${ }^{[17]}$. 
$\mathrm{Bu}$ çalıșmadan kısa bir süre sonra Yamamura ve arkadașları tarafından favipiravir, steroid ve heparinden olușan kombine bir tedavinin ciddi COVID-19 infeksiyonunda etkinliği daha küçük bir hasta grubunda araștırılmıștır. Calıșmaya dahil edilen hastalara favipiravir (1. gün 3600 mg/gün, 14. güne kadar $1600 \mathrm{mg} /$ gün), metilprednizolon, düșük molekül ağırlıklı heparin veya standart heparin uygulanmıștır. Calıșma kapsamında mekanik ventilasyon ihtiyacı olan 13 hasta (yaș ortalaması 63 ve \%69 erkek) analiz edilmiștir. COVID-19 tanısı ile favipiravir tedavisi bașlanması arasında geçen süre ortalama dokuz gündür. Calıșma sonucunda yazarlar; mekanik ventilasyon uygulanan COVID-19 hastalarında favipiravirin inflamatuvar yanıtları kısmen kontrol altına alabildiği, ancak hem bu yanıtları hem de solunum fonksiyonlarını tamamen duizeltemediği yorumunu yapmıștır. Favipiravir sonrası inflamasyon ve sitokin firtınasının devam ettiği ve bu durumun steroid ile kontrol altına alınabildiği vurgulanmıștır ${ }^{[18]}$.

Favipiravirin kullanıldı̆̆ı ülkelerden biri olan Rusya'da Ivashchenko ve arkadașları tarafından Nisan ve Mayıs 2020 tarihleri arasında yapilmıs cok merkezli, açık etiketli, randomize çalıșma ön sonuclarında favipiravir tedavisi, standart bakım ile karșılaștırılmıștır. Calıșmaya PCR testleri pozitif, orta derecede COVID-19 pnömonisi olan hastalar dahil edilmiștir. Hastalar ilk gün 3200 mg/gün ve sonrasında 14. güne kadar 1200 mg/gün grubu, ilk gün $3600 \mathrm{mg} /$ gün ve sonrasinda 14. güne kadar 1600 mg/gün grubu ve standart bakım grubu olarak 1:1:1 oranında randomize edilmistir. Calıșmada her gruba 20, toplamda 60 hasta dahil edilmiștir. Standart bakım grubunda hastaların \%75'ine hidroksiklorokin veya klorokin verilmis, \%5'ine lopinavir/ritonavir verilmis, \%20'sine ise patojene özgü bir ajan verilmemiștir. Favipiravir için randomizasyondaki iki doz rejimi ile benzer virolojik yanıtlara ulașıldığı saptanmıștır. Tedavinin 5. gününde favipiravir ile tedavi edilen hastaların \%62.5'inde standart bakım verilen hastaların ise \%30'unda viral klirense ulașılmıștır $(p=0.018)$. Onuncu guinde ise bu oranlar sirasiyla \%92.5 ve $\% 80$ olmustur $(p=0.155)$. Ateșin normalleșme $\left(<37^{\circ} \mathrm{C}\right)$ süresi favipiravir grubunda ortanca iki gün, standart bakım grubunda ise dört gün olarak saptanmiștır $(p=0.007)$. On beșinci günde toraks BT bulguları iki grupta da benzer oranlarda iyileș- me göstermiștir (favipiravir grubu \%90 ve standart bakım grubu \%80, $\mathrm{p}=0.283$ ).

Tedavinin 15. gününde favipiravir 1600/600 mg doz grubundaki hastaların \%65'i, 1800/800 mg doz grubundaki hastaların \%85'i, standart bakım grubundaki hastaların ise \%85'i hastaneden taburcu edilmiș ya da Dünya Sağlık Örgütü Klinik Iyileșme Sıralama Ölçeği (World Health Organization Ordinal Scale for Clinical Improvement, WHO-OSCI) skor 2 düzeyine ulașmıstır ${ }^{[19]}$.

Favipiravir tedavisinin araștırıldığı yayımlanan en güncel calıșmalardan biri Doi ve arkadașları tarafından 2 Mart-18 Mayıs 2020 tarihleri arasında Japonya'da yapılan calıșmadır. Bu çalıșmada erken tedavi grubu birinci günden itibaren, gec tedavi grubu ise altıncı günden itibaren favipiravir tedavisi almıștır. Calıșmaya 16 yas ve üzeri asemptomatik veya hafif semptomları olan hastalar dahil edilmiștir. Calıșmada favipiravir ilk gün 3600 mg/gün, sonraki günler ise 1600 mg/gün dozunda uygulanmıstır. Calıșmaya dahil edilen hastaların yas ortancası 50 yil ve \%64.1'i erkektir. Dahil edilme sırasında hastaların \%36.4'ünün $>37.5^{\circ} \mathrm{C}$ vücut sıcaklığına sahip olduğu belirtilmiștir. Randomizasyondan ortanca dört gün önce PCR testi pozitifliği ve yedi gün önce ateș varlığı bildirilmiștir. Calıșmada cinsiyet oranlarındaki dengesizlik dișında iki grubun temel özellikleri benzerdir. Bu çalıșmada altıncı günde viral klirens oranında iki tedavi grubu arasında fark görülmemiștir (\%66.7 ve \%56.1). Ateșin dusșmesi $\left(<37.5^{\circ} \mathrm{C}\right)$ erken tedavi grubunda ortalama 2.5 gün, gec tedavi grubunda ise 3.2 gün olarak saptanmıștır. Tedavinin ikinci gününde erken tedavi grubunda ates düsüsüunün gec tedavi grubuna göre daha fazla olduğu belirtilmiștir. Calıșmada 65 yaș ve üzeri hastalar incelendiğinde altıncı günde viral klirens oranının erken tedavi grubunda daha fazla olduğu gözlenmiștir $(\% 88.9 \text { ve \%0) })^{[10]}$.

Çok kücük bir hasta grubunu $(n=8)$ içeren bir calıșmada ise $\mathrm{Fu}$ ve arkadașları tarafından viral klirensinde gecikme olan asemptomatik hastalarda favipiravir tedavisi değerlendirilmiștir. Tedavi bașlanmasından önceki ortanca 61 gün boyunca hastaların PCR test sonucu pozitif olarak saptanmiștır. Hastalara ilk gün 3200 mg, daha sonra ise 10. guine kadar $1200 \mathrm{mg} /$ gun favipiravir tedavisine ek olarak favipiravir öncesi klorokin, umi- 
fenovir gibi farklı tedaviler verilmiștir. Sadece bir hastaya 10 gün, diğerlerine dört-dokuz gün tedavi verilmiștir. Bir hasta hariç tüm hastalarda altı gün içinde PCR negatifliğine ulașlmıștır ve ortanca viral saçlım süresi üç gün olarak belirlenmiștir ${ }^{[20]}$.

Doğrudan favipiravir etkilerini değerlendiren çalıșmalar dıșında bașka amaçlarla yürütülmüs bazı calıșmalar da favipiravir etkinliğine dair veriler ve yorumlar içermektedir. Ancak bu calıșmaların bir kısmında tedavi etkinliği ile ilgili veri yoktur, kombine tedaviler kullanılmıștır ve cok sayıda karıștırıcı faktör vardır ${ }^{[21,22]}$

$\mathrm{Bu}$ derleme yazıldığı sıradaki en güncel çalıșmalardan ilkinde Kocayiğit ve arkadașları retrospektif bir sekilde, gözlemsel olarak kritik COVID-19 hastalarında favipiravir ve lopinavir/ritonavir etkinliğini karșılaștırmıștır. Bu çalıșmada ardıșık 107 hasta değerlendirilmiș, favipiravir grubundaki hastaların \%66.2'sinin, lopinavir/ritonavir grubundaki hastaların ise \%54.8'inin hayatını kaybettiği $(p=0.237)$ ve taburcu olan hastalar arasında favipiravir kullananların yoğun bakım ünitesinde yatıș süresinin daha kısa olduğu saptanmıștır (6.7 ve 11.6 gün, $p=0.010)^{[23]}$. Lou ve arkadașları tarafindan yapılan bir diğer açı etiketli, randomize, kontrollü güncel calıșmada baloksavir ve favipiravir (ilk doz 1600 veya $2200 \mathrm{mg}$, daha sonra günde üc kez $600 \mathrm{mg}$ ) tedavilerini kontrol grubu (lopinavir/ritonavir, darunavir/kobisistat veya umifenovir ve inhale interferon- $\alpha$ ) ile karșlaștırmıștır. Bu çalıșmanın ön in vitro analizinde baloksavir EC50 değeri 5.48 $\mu \mathrm{M}$, favipiravir EC50 değeri ise $100 \mu \mathrm{M}$ olarak saptanmıștır. On dördüncü günde viral negatifliğe ulașma oranı baloksavir grubunda \%70, favipiravir grubunda \%77, kontrol grubunda ise \%100 olarak bulunmuștur. Yeterli virolojik etki ve klinik yarar sağlanamamıș olmasının nedenlerinden biri olarak antiviral etkinlik için yeterli konsantrasyona ulașlamamıs olabileceği belirtilmiștir ${ }^{[24]}$.

\section{Givenirlilik}

Cai ve arkadașları tarafından yapılan randomize calıșmada favipiravir grubunda hastaların \%11.4'ünde, kontrol grubunda ise \%55.6'sında advers olay olduğu saptanmıștır $(p<0.001)^{[17]}$.

Rusya'da yürütülen çalıșmada favipiravir grubunda hastaların \%17.5'inde istenmeyen etkiler gözlendiği (diyare, bulantı, kusma, göğüs ağrısı, transaminaz düzeylerinde artış) ve bu etkilerin hastaların \%5'inde ilac kesilmesine neden olduğu belirtilmiștir ${ }^{[19]}$. Doi ve arkadașlarının çalıșmasında 82 hastada toplam 144 istenmeyen etki raporlanmıștır. En sik ortaya cıkan istenmeyen etkiler hiperürisemi, serum trigliseridlerinde ve ALT değerinde artıs olarak saptanmıștır[10]. Türkiye'de yapılan bir calıșmada favipiravir verilen hastalarda bulantı, kusma ve transaminaz düzeylerinde art1șin hidroksiklorokin ve azitromisin verilenlere göre daha fazla olduğu saptanmıștır ${ }^{[21]}$. Yine Türkiye'de 220 pediatrik COVID-19 hastasının 5'inde favipiravir ve hidroksiklorokin kombinasyonunun kullanıldığı bir çalıșmada herhangi bir hastada istenmeyen ilac etkisi saptanmadığı belirtilmiștir ${ }^{[25]}$. Bir diğer calıșmada ise en az bes gün favipiravir ile tedavi edilen hastalar retrospektif olarak değerlendirilmiștir. Favipiravir tedavisi sonrası lökosit ve INR düzeylerinde bir değișim olmadığı; ortalama eritrosit sayısının değerinin $4.33 \mathrm{M} / \mu \mathrm{L}$ 'den 4.16 $\mathrm{M} / \mu \mathrm{L}$ 'ye düștüğü $(\mathrm{p}=0.003)$, ortalama nötro-

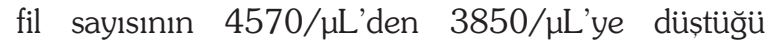
$(p=0.001)$, ortalama lenfosit sayısının ise 1220/ $\mu \mathrm{L}$ 'den $1840 / \mu \mathrm{L}$ düzeyine yükseldiği saptanmıștır ( $p<0.001)$, ayrica hemoglobin ve hematokrit düzeylerinde de anlaml azalmalar ve trombosit sayısında anlamlı artıș olmuștur ${ }^{[26]}$.

\section{Vaka Raporları}

Literatürde favipiravir tedavisinin uygulandığı hastaların bildirildiği 23 vaka raporu bulunmaktadır, bu raporlarda toplam 36 hasta değerlendirilmiș ve genel olarak favipiravir tedavisi ile PCR pozitifliği ve klinik iyileșmenin sağlanması konular1 üzerinde durulmuștur. Belirtilen vaka raporları Tablo 1'de özetlenmistir ${ }^{[27-45]}$.

\section{Guivenilirlik}

Bir vaka raporunda daha önce hiperürisemi ve gut atağı öyküsü olan bir hastada 14 gün favipiravir tedavisi sonrası ürik asit düzeyinde artış gözlendiği ve hastada akut gut artriti geliștiği bildirilmiștil $^{[46]}$. Bașka bir raporda ise iki hastada favipiravire bağlı ateș geliștiği rapor edilmiștir. COVID-19'a bağlı semptomlarda gerileme olmasına rağmen favipiravir uygulaması sonrası hastaların vuicut sıcaklığı değerlerinde artıș olduğu ve kapsamlı değerlendirme sonucunda ateși ilișkilendirecek bașka bir neden bulunamadığı için ates favipiravire bağlanmıștır. Favipiravirin kesilmesin- 
Tablo 1. Favipiravir ile tedavi edilen vakalar konusundaki raporlar

\begin{tabular}{|c|c|c|c|}
\hline Yazar & Tedavi & Hasta(Iar) & Sonuç \\
\hline Koba ve arkadaşları (27) & $\begin{array}{l}\text { Lopinavir/ritonavir ve } \\
\text { favipiravir kombinasyonu }\end{array}$ & 3 hasta & $\begin{array}{l}\text { Hastalarda belirgin düzelme } \\
\text { gözlenmiş ve önemli bir yan etki } \\
\text { ortaya çıkmamıştır. }\end{array}$ \\
\hline Dauby ve arkadaşları (28) & $\begin{array}{l}\text { Favipiravir (ilk gün } 3200 \\
\text { mg, daha sonra ise } 7 . \\
\text { güne kadar } 1200 \mathrm{mg} / \\
\text { gün) } \\
2 \text { hastada tek doz } \\
\text { tosilizumab }\end{array}$ & 4 kritik hasta & $\begin{array}{l}\text { Hastalardan biri septik şok ve çoklu } \\
\text { organ yetmezliği nedeniyle kaybe- } \\
\text { dilmiştir. Hayatını kaybeden hasta } \\
\text { hariç tüm hastalarda favipiravir teda- } \\
\text { visi süresince lenfosit sayısında artış } \\
\text { olduğu belirtilmiştir. }\end{array}$ \\
\hline $\begin{array}{l}\text { Takahashi ve arkadaşları } \\
\text { (29) }\end{array}$ & $\begin{array}{l}\text { Favipiravir (ilk gün } 3600 \\
\text { mg, daha sonra ise } 14 . \\
\text { güne kadar } 1600 \mathrm{mg} /\end{array}$ & 3 kritik hasta & $\begin{array}{l}\text { Tedavi ile hastalardaki pnömonilerin } \\
\text { düzelme gösterdiği ve oksijen ihti- } \\
\text { yacının azaldığı belirtilmiştir. }\end{array}$ \\
\hline
\end{tabular}
gün)

2 hastada favipiravir dışında steroid, antibakteriyel ve antiviral ajanlar da kullanılmıştır

Hosoba ve arkadaşları (30)

Murohashi ve arkadaşları (31)

Inoue ve arkadaşları (32)

Favipiravir (ilk gün 3200 $\mathrm{mg}$, daha sonra ise 1200 mg/gün)

Favipiravir ve metilprednizolon kombinasyonu ile tedavi edilmiş (ek olarak azitromisin, siklesonid, IVIG gibi tedaviler de verilmiş)

Beş gün boyunca steroid ve favipiravir kombinasyonu

Taşkın ve arkadaşları (33) Favipiravir (5 gün) ve tosilizumab (tek doz)

Daha önce

hidroksiklorokin, azitromisin ve oseltamivir kullanılmış Takashi ve arkadaşları (34) Favipiravir

T-hücreli lösemi/ lenfomalı hasta

11 ağır pnömoni hastası

Kronik obstrüktif akciğer hastalığı olan 58 yaşında hasta

Atipik Sweet sendromlu hasta

73 yaşında, erkek hasta

Nakamura ve arkadaşları (35)

Thammathiwat ve arkadaşları (36)
Semptomların

başlangıcından 8 gün sonra favipiravir ve

nafamostat kombinasyonu

(3 kere tosilizumab)

Darunavir/ritonavir,

hidroksiklorokin, azitromisin ve favipiravir ve tek doz tosilizumab
Herhangi bir

ek hastalığı

olmayan, 45

yaşındaki erkek

hasta

Böbrek nakil hastası
Antipiretik bir ajan kullanılmadan ateşin ve CRP'nin önemli bir şekilde düştüğü vurgulanmıştır.

Hastaların 10'unda tedaviye yanıtın iyi olduğu, oksijen veya ventilatör ihtiyacının ortadan kalktığı belirtilmiştir.

Entübe olan hasta tedavinin 5. günü ekstübe edilmiş ve 15 . günde viral klirensi sağlanarak 21. günde taburcu edilmiştir.

24 saat içinde ateşinde düzelme gözlenmiştir.

Hastanın klinik bulgularında düzelme favipiravir tedavi başlandıktan 2 gün sonra başladığı için, favipiravirin düzelmeye katkıda bulunmuş olabileceği yorumu yapılmıştır.

Entübe edilen hasta hastane yatışının 38. gününde herhangi bir oksijen desteği olmaksızın taburcu edilebilmiştir.

Favipiravir dışındaki diğer tedaviler 1 veya 2 gün uygulanarak kesilmiş, favipiravir tedavisine ise devam edilmiştir. Tedavinin 7. günü ateş, diyare; 10 . günü ise solunum ihtiyacı ortadan kalkmıştır. 
Tablo 1. Favipiravir ile tedavi edilen vakalar konusundaki raporlar (devamı)

\begin{tabular}{|c|c|c|c|}
\hline Yazar & Tedavi & Hasta(lar) & Sonuç \\
\hline Yatomi ve arkadaşları (37) & $\begin{array}{l}\text { Lopinavir/ritonavir, } \\
\text { klorokin ve favipiravir } \\
\text { (gastrik tüp vasıtası ile ilk } \\
\text { gün } 3600 \text { mg, daha sonra } \\
\text { ise } 5 \text {, qüne kadar } 1600\end{array}$ & $\begin{array}{c}82 \text { yaşında, erkek } \\
\text { hasta }\end{array}$ & $\begin{array}{c}\text { Remdesivir uygulaması sonrası nega- } \\
\text { tif PCR'a ulaşılmış; ayrıca ECMO gibi } \\
\text { invaziv girişimlerin sonlandırılması } \\
\text { sağlanmıştır. }\end{array}$ \\
\hline
\end{tabular}

Sugiyama ve arkadaşları (38)

Tatar ve arkadaşları (39)

Ono ve arkadaşları (40)

Koshi ve arkadaşları (41)

Jafari ve arkadaşları (42)

Sakamaki ve arkadaşları (43)

Kondo ve arkadaşları (44)

Moolasart ve arkadaşları (45)

$$
\mathrm{mg} \text { /gün), remdesivir }
$$

Kortikosteroid ve favipiravir (ilk gün 3600 $\mathrm{mg}$, daha sonra ise 1600 $\mathrm{mg} /$ gün)

Öncesinde siklesonid ve azitromisin

IVIG ve favipiravir (ilk gün $2400 \mathrm{mg}$, daha sonra ise 4 gün boyunca 1200 mg/ gün) Oseltamivir, hidroksiklorokin, moksifloksasin ve meropenem

Favipiravir

Favipiravir (ilk gün 3600 mg/gün, daha sonra 14 . güne kadar 1600 mg/gün dozunda)

Öncesinde lopinavir/

ritonavir ve siklesonid

Konvelasan plazma ve favipiravir

Meropenem, azitromisin ve hidroksiklorokin

Oksijen desteği ve favipiravir (ilk gün 3600 $\mathrm{mg}$, daha sonra ise 14 . güne kadar 1600 mg/ gün)

Favipiravir

Favipiravir, lopinavir/ritonavir, hidroksiklorokin
56 yaşında, erkek hasta

66 yaşında, kadın, böbrek nakli hastası

COVID-19 sonrası reaktif artrit gelişen hasta

Son dönem böbrek yetmezliğindeki, 52 yaşında, kadın hasta

26 yaşında, ikiz bebeklerine hamile hasta

54 yaşında, erkek hasta

Eş zamanlı olarak influenza A ile infekte, 57 yaşındaki hasta 47 günlük erkek hasta
Hastanın ateş durumunun normale döndüğü ve solunum yetmezliğinin düzeldiği gözlenmiştir.

Yatışın 9. gününde oksijen gereksinimi ve CRP değerlerinde azalma olmuş, 10. gün çekilen toraks BT'de iyileşme saptanmış ve 11 . günde oksijen tedavisi kesilmiştir.

Yatışın 4. gününde ise ARDS gelişmiş ve hasta entübe edilmiştir. 11. günde hasta ekstübe edilmiş ve 14 günlük favipiravir tedavisi tamamlanmıştır. Hastada yan etki olarak hafif düzeyde hiperürisemi geliştiği belirtilmiştir.

Hastada kademeli bir iyileşme gözlenmiş, 2 hafta sonra viral yükün saptanabilir düzeyin altına inmesi ile hasta ekstübe edilmiştir.

Tedavinin 6. gününde uygulanmaya başlanan konvelasan plazma ve favipiravir kombinasyonu ile toraks BT bulgularında dramatik bir yanıt gözlendiği belirtilmiştir.

Yatıştan 3 gün sonra hasta entübe edilmiş ve 6 gün sonra hasta

ECMO'ya alınmıştır. 15 gün sonra ise hastanın solunum bulguları düzelmiş ve ECMO kesilmiştir.

Hastanın başarıyla tedavi edildiği bildirilmiştir.

PCR testi 10 günde negatifleşmiş ve tedavinin 8 . gününde klinik durum iyileşmiştir.

ARDS: Akut solunum sıkıntısı sendromu, BT: Bilgisayarlı tomografi, CRP: C-reaktif protein, ECMO: Ekstrakorporeal membran oksijenasyonu, IVIG: İntravenöz immunoglobulin, PCR: Polimeraz zincir reaksiyonu. 
den sonra iki hastada da vücut 1s1s1 normale dönmüstür [47].

\section{SONUÇ}

COVID-19 tedavisinde henüz istenen düzeyde etkinliği kanıtlanmıs bir antiviral ajan olmamakla birlikte, remdesivir iyi tasarlanmıș calıșmalarla etkisi test edilmiș bir ajandır. Favipiravir ise daha az destekleyici kanıt olmasına rağmen, remdesivir ile benzer etki mekanizmasına sahip olmasının yanında oral uygulama avantajı ve hafif düzeydeki istenmeyen etkileri ile dikkat ceken bir antiviraldir. Oral uygulanabiliyor olması ayaktan takip edilen COVID-19 hastalarında da kolaylıkla kullanılabilmesine olanak sağlamaktadır. Hastaların büyük bir kısmının hafif-orta düzeyde ve evde tedavi/ takip edilmekte olduğu düșuinüldüğünde, favipiravir tedavisinin lojistik açıdan kolaylık sağladığı görülmektedir. Ancak favipiravirin tablet formülasyonunda olması ve kritik hastaların genellikle oral alım sorunu kullanımını kısıtlamaktadır. Favipiravirin nazogastrik tüp ile uygulanabildiği daha önce bazı calıșmalarda gösterilmiștir ${ }^{[5,9,10]}$. Her tabletin 200 mg olması ve hem yükleme dozu hem de idame dozlar için cok sayıda tablet gereksinimi ise dezavantajlarından biridir.

Semptomların ortaya cıkıșından sonra mümkün olan en kısa sürede uygulanması ile viremi ve viral saçlımin azaltılarak semptomların ve toplumsal bulașın azaltılması olasıdır. Ayrıca Fu ve arkadașları tarafından yapılmıș calıșma kücuuk boyutlu bir calıșma olsa da asemptomatik ancak uzun süre kalıcı viral pozitifliğe sahip hastaların favipiravirle tedavi edilerek bulaștırıcılıklarının azaltılabileceğini düșündürmektedir. Buna ek olarak, hastalarda favipiravir öncesi bașka tedaviler aldıkları halde PCR negatifliğine ulasslamazken, favipiravir ile PCR negatifliğine ulașılmıș olması, favipiravirin SARS-CoV-2'ye karșı viral etkinliği hakkında olumlu düșünceler olușturmaktadır.

Sonuc olarak, favipiravir semptomatik COVID-19 hastalarının tedavisinde bir seçenektir ancak güvenli kullanımın sağlanması için çok daha fazla hastanın dahil edildiği ve daha uzun takip sürelerini içeren randomize, kontrollü çalısmaların planlanması ve devam eden bu tarz calıșmaların sonuçlarını değerlendirmek gerekmektedir.

\section{ÇIKAR ÇATIȘMASI}

Yazar bu makale ile ilgili herhangi bir c1kar catıșması bildirmemiștir.

\section{KAYNAKLAR}

1. Furuta $Y$, Gowen BB, Takahashi K, Shiraki K, Smee DF, Barnard DL. Favipiravir (T-705), a novel viral RNA polymerase inhibitor. Antiviral Res 2013;100(2):446-54.

2. Oestereich L, Lüdtke A, Wurr S, Rieger T, Muñoz-Fontela C, Günther S. Successful treatment of advanced Ebola virus infection with T-705 (favipiravir) in a small animal model. Antiviral Res 2014;105:17-21.

3. Sissoko D, Laouenan C, Folkesson E, M'Lebing AB, Beavogui $A H$, Baize $S$, et al. Experimental treatment with favipiravir for Ebola Virus Disease (the JIKI Trial): A historically controlled, single-arm proof-of-concept trial in Guinea. PLoS Med 2016;13(3):e1001967.

4. Bouazza N, Treluyer J-M, Foissac F, Mentré F, Taburet A-M, Guedj J, et al. Favipiravir for children with Ebola. Lancet 2015;385(9968):603-4.

5. Wang $M$, Cao R, Zhang L, Yang X, Liu J, Xu M, et al. Remdesivir and chloroquine effectively inhibit the recently emerged novel coronavirus (2019-nCoV) in vitro. Cell Research 2020;30(3):269-71.

6. Du Y-X, Chen X-P. Favipiravir: Pharmacokinetics and concerns about clinical trials for 2019-nCoV infection. Clin Pharmacol Ther 2020;108(2):242-7.

7. Toyama Chemicals. Summary of Product Characteristics of Avigan. Accessed date: 17.12.2020 Available from: https:// www.cdc.gov.tw/File/Get/ht8jUiB_Ml-aKnlwstwzvw,

8. Madelain V, Nguyen TH, Olivo A, de Lamballerie X, Guedj J, Taburet $A M$, et al. Ebola Virus infection: Review of the pharmacokinetic and pharmacodynamic properties of drugs considered for testing in human efficacy trials. Clin Pharmacokinet 2016;55(8):907-23.

9. Furuta $Y$, Komeno T, Nakamura T. Favipiravir (T-705), a broad spectrum inhibitor of viral RNA polymerase. Proc Jpn Acad Ser B Phys Biol Sci 2017;93(7):449-63.

10. Doi $Y$, Hibino $M$, Hase $R$, Yamamoto $M$, Kasamatsu $Y$, Hirose $M$, et al. A prospective, randomized, open-label trial of early versus late favipiravir in hospitalized patients with COVID-19. Antimicrob Agents Chemother 2020;64(12):e01897-20.

11. Eloy $P$, Solas $C$, Touret $F$, Mentré F, Malvy D, de Lamballerie $X$, et al. Dose rationale for favipiravir use in patients infected with SARS-CoV-2. Clin Pharmacol Ther 2020;108(2):188.

12. Irie K, Nakagawa A, Fujita $H$, Tamura $R$, Eto $M$, Ikesue $H$, et al. Pharmacokinetics of favipiravir in critically ill patients with COVID-19. Clin Transl Sci 2020;13(5):880-5.

13. Hirai D, Yamashita D, Seta K. Favipiravir for COVID-19 in a patient on hemodialysis. Am J Kidney Dis 2020:S02726386(20)31006-4. 
14. Pharmaceuticals and Medical Devices Agency. Report on the Deliberation Results Avigan, Japan. Evaluation and Licensing Division, Pharmaceutical and Food Safety Bureau. Available date: 17.12.2020. Available from: www.pmda. go.jp/files/000210319.pdf.

15. Pilkington $V$, Pepperrell $T$, Hill A. A review of the safety of favipiravir - a potential treatment in the COVID-19 pandemic? J Virus Eradication 2020;6(2):45-51.

16. Kumagai $Y$, Murakawa $Y$, Hasunuma $T$, Aso $M$, Yuji $W$, Sakurai $T$, et al. Lack of effect of favipiravir, a novel antiviral agent, on QT interval in healthy Japanese adults. Int J Clin Pharmacol Ther 2015;53(10):866-74.

17. Cai Q, Yang M, Liu D, Chen J, Shu D, Xia J, et al. Experimental treatment with favipiravir for COVID-19: An open-label control study. Engineering (Beijing) 2020;6(10):1192-8.

18. Yamamura H, Matsuura H, Nakagawa J, Fukuoka H, Domi $H$, Chujoh S. Effect of favipiravir and an anti-inflammatory strategy for COVID-19. Crit Care 2020;24(1):413.

19. Ivashchenko AA, Dmitriev KA, Vostokova NV, Azarova VN, Blinow AA, Egorova AN, et al. AVIFAVIR for treatment of patients with moderate COVID-19: Interim results of a phase II/III multicenter randomized clinical trial. Clin Infect Dis 2020 Aug 9:ciaa1176.

20. Fu D, Cao R, Zhao L, Li W, Zhong W, Wen J. Oral favipiravir for patients with delayed SARS-CoV-2 viral RNA clearance: a case series. Crit Care 2020;24(1):578.

21. Çalik Başaran N, Uyaroğlu OA, Telli Dizman G, Özişik L, Şahin TK, Taş Z, et al. Outcome of non-critical COVID-19 patients with early Hospitalization and early antiviral treatment outside the ICU. Turk J Med Sci 2020 Jul 28.

22. Doi K, Ikeda M, Hayase N, Moriya K, Morimura N. Nafamostat mesylate treatment in combination with favipiravir for patients critically ill with Covid-19: a case series. Crit Care 2020;24(1):392.

23. Kocayiğit H, Özmen Süner K, Tomak Y, Demir G, Yaylacı S, Dheir $H$, et al. Observational study of the effects of Favipiravir vs Lopinavir/Ritonavir on clinical outcomes in critically III patients with COVID-19. J Clin Pharm Ther 2020 Oct 31.

24. Lou Y, Liu L, Yao H, Hu X, Su J, Xu K, et al. Clinical outcomes and plasma concentrations of Baloxavir Marboxil and Favipiravir in COVID-19 patients: An exploratory randomized, controlled trial. Eur J Pharm Sci 2020:105631.

25. Cura Yayla BC, Özsürekçi Y, Aykaç K, Derin Oygar P, Laçinel Gürlevik S, ilbay S, et al. Characteristics and management of children with COVID-19 in Turkey. Balkan Med J 2020;37(6):341-7.

26. Yaylaci S, Dheir $H$, Şenocak D, Genc $A B$, Kocayigit $H$, Çekiç $D$, et al. The effects of favipiravir on hematological parameters of cov1d-19 patients. Revista da Associação Médica Brasileira. 2020;66:65-70.

27. Koba $H$, Yoneda $T$, Kaneda $T$, Ueda $T$, Kimura $H$, Kasahara $K$. Severe coronavirus disease 2019 (COVID-19) pneumonia patients treated successfully with a combination of lopinavir/ritonavir plus favipiravir: Case series. Clin Case Rep 2020:10.1002/ccr3.3358
28. Dauby N, Van Praet S, Vanhomwegen C, Veliziotis I, Konopnicki D, Roman A. Tolerability of favipiravir therapy in critically ill patients with COVID-19: A report of four cases. J Med Virol 2020 Sep 4.

29. Takahashi H, Iwasaki Y, Watanabe T, Ichinose N, Okada $Y$, Oiwa A, et al. Case studies of SARS-CoV-2 treated with favipiravir among patients in critical or severe condition. Int J Infect Dis 2020;100:283-285.

30. Hosoba R, Makita S, Shiotsuka M, Kobayashi O, Nakano $K$, Muroya M, et al. COVID-19 pneumonia in a patient with adult T-cell leukemia-lymphoma. J Clin Exp Hematop 2020;60(4):174-178.

31. Murohashi K, Hagiwara E, Kitayama T, Yamaya T, Higa K, Sato $Y$, et al. Outcome of early-stage combination treatment with favipiravir and methylprednisolone for severe COVID-19 pneumonia: A report of 11 cases. Respir Investig 2020;58(6):430-4.

32. Inoue $H$, Jinno $M$, Ohta S, Kishino $Y$, Kawahara T, Mikuni $H$, et al. Combination treatment of short-course systemic corticosteroid and favipiravir in a successfully treated case of critically ill COVID-19 pneumonia with COPD. Respir Med Case Rep 2020;31:101200.

33. Taşkın B, Vural S, Altuğ E, et al. Coronavirus 19 presenting with atypical Sweet's syndrome. I Eur Acad Dermatol Venereol 2020;34(10):e534-e5.

34. Takahashi $N$, Abe $R$, Hattori $N$, Matsumura $Y$, Oshima T, Taniguchi $T$, et al. Clinical course of a critically ill patient with severe acute respiratory syndrome coronavirus 2 (SARS-CoV-2). J Artif Organs 2020:1-4.

35. Nakamura $H$, Miyagi $K$, Otsuki M, Higure $Y$, Nishiyama $N$, Kinjo $T$, et al. Acute hypertriglyceridaemia caused by tocilizumab in a patient with severe COVID-19. Intern Med 2020;59(22):2945-9.

36. Thammathiwat T, Tungsanga S, Tiankanon K, Torvorapanit $P$, Chumpangern W, Udomkarnjananun $S$, et al. A case of successful treatment of severe COVID-19 pneumonia with favipiravir and tocilizumab in post-kidney transplant recipient. Transpl Infect Dis 2020:e13388-e.

37. Yatomi M, Takazawa T, Yanagisawa K, Kanamoto M, Matsui Y, Tsukagoshi $H$, et al. Improvement of severe COVID-19 in an elderly man by sequential use of antiviral drugs. Case Rep Infect Dis 2020;2020:8814249.

38. Sugiyama $Y$, Tsuchiya T, Tanaka R, Ouchi A, Motoyama A, Takamoto $T$, et al. Cerebral venous thrombosis in COVID-19-associated coagulopathy: A case report. J Clin Neurosci 2020;79:30-2.

39. Tatar E, Karatas M, Bozaci I, Ari A, Acar T, Simsek C, et al. Intravenous immunoglobulin and favipiravir treatment for a kidney transplant patient with severe Covid-19 pneumonia. Transfus Apher Sci 2020:102904.

40. Ono K, Kishimoto $M$, Shimasaki T, Uchida H, Kurai D, Deshpande GA, et al. Reactive arthritis after COVID-19 infection. RMD Open 2020;6(2):e001350. 
41. Koshi E, Saito S, Okazaki M, Toyama Y, Ishimoto T, Kosugi $T$, et al. Efficacy of favipiravir for an end stage renal disease patient on maintenance hemodialysis infected with novel coronavirus disease 2019. CEN Case Rep 2020:1-6.

42. Jafari $R$, Jonaidi-Jafari $N$, Dehghanpoor F, Saburi A. Convalescent plasma therapy in a pregnant COVID-19 patient with a dramatic clinical and imaging response: A case report. World J Radiol 2020;12(7):137-41.

43. Sakamaki I, Morinaga Y, Tani H, Takegoshi Y, Fukui $Y$, Kawasuji $\mathrm{H}$, et al. Monitoring of viral load by RT-PCR caused decision making to continue ECMO therapy for a patient with COVID-19. J Infect Chemother 2020;26(12):1324-7.

44. Kondo Y, Miyazaki S, Yamashita R, Ikeda T. Coinfection with SARS-CoV-2 and influenza A virus. BMJ Case Rep 2020;13(7):e236812.

45. Moolasart V, Wongsawat J, Phokhom P, Thienthong V. Favipiravir-based regimen for coronavirus disease 2019 pneumonia for a 47-day-old male newborn. SAGE Open Med Case Rep 2020;8:2050313×20964046.
46. Hase $R$, Kurata $R$, Ishida K, Kurita T, Muranaka E, Mito H. Acute gouty arthritis during favipiravir treatment for Coronavirus Disease 2019: A case report. Intern Med 2020;59(18):2327-9.

47. Takoi H, Togashi Y, Fujimori D, Kaizuka H, Otsuki S, Wada T, et al. Favipiravir-induced fever in coronavirus disease 2019: A report of two cases. Int J Infect Dis 2020;101:188-90.

\section{Yazıșma Adresi/Address for Correspondence} Emre KARA

Hacettepe Üniversitesi Eczacılık Fakültesi,

Klinik Eczacılık Anabilim Dalı,

Ankara-Türkiye

E-posta: emrekara@hacettepe.edu.tr 